\title{
Fetal growth and hemodynamics during SARS-CoV-2 infection: a short literature review
}

\author{
Giuseppe Rizzo ${ }^{1,}$, Ilenia Mappa ${ }^{1}$, Pavjola Maqina ${ }^{1}$, Victoria O. Bitsadze ${ }^{2}$, \\ Jamilya Kh. Khizroeva ${ }^{2}$, Alexander D. Makatsariya ${ }^{2}$ \\ ${ }^{1}$ University of Rome Tor Vergata, Fondazione Policlinico Tor Vergata, \\ Division of Maternal Fetal Medicine, Ospedale Cristo Re \\ 00167, Rome, Italy \\ ${ }^{2}$ Sechenov First Moscow State Medical University (Sechenov University) \\ 8/2, Trubetskaya str., Moscow, 119991, Russia
}

\begin{abstract}
Severe acute respiratory syndrome coronavirus 2 (SARS-CoV-2) is a virus that, having crossed species, has caused human disease from 2019 - COrona VIrus Disease 2019 (COVID-19). Pregnant women are potentially at high risk of contracting SARS-CoV-2 infection when compared to non-pregnant matched controls. Pregnancy is also complicated with a higher risk of developing severe SARS-CoV-2, including respiratory diseases, admission to the intensive care unit and mortality, even after adjusting for confounding risk factors. Moreover, data on the effect on fetal outcome including preterm delivery and perinatal morbidity are still conflicting, the risk of vertical transmission (i.e., transmission of SARS-CoV-2 from the mother to the fetus or the newborn) is considered low but there is evidence that a significant proportion of placentas where SARSCoV-2 occurred during pregnancy show histopathological findings suggesting placental hypoperfusion and inflammation. In this review we will present the available data on the effects of SARS-CoV-2 infection on fetal growth and maternal hemodynamics
\end{abstract}

Keywords: SARS-CoV-2-infection; COVID-19; fetal growth; uterine artery Doppler; fetal Dopplers

MeSH terms:

PREGNANCY COMPLICATIONS, INFECTIOUS - DIAGNOSIS

PREGNANCY COMPLICATIONS, INFECTIOUS - PHYSIOPATHOLOGY

SEVERE ACUTE RESPIRATORY SYNDROME - DIAGNOSIS

SEVERE ACUTE RESPIRATORY SYNDROME - COMPLICATIONS

SEVERE ACUTE RESPIRATORY SYNDROME - PHYSIOPATHOLOGY

FETUS - DIAGNOSTIC IMAGING

FETUS - PHYSIOPATHOLOGY

PLACENTAL CIRCULATION

For citation: Rizzo G., Mappa I., Maqina P., Bitsadze V.O., Khizroeva J.Kh., Makatsariya A.D. Fetal growth and hemodynamics during SARS-CoV-2 infection: a short literature review. Sechenov Medical Journal. 2021; 12(2): $20-25$. https://doi.org/10.47093/2218-7332.2021.12.2.20-25

CONTACT INFORMATION:

Giuseppe Rizzo, MD, Professor and Chairman, University of Rome Tor Vergata, Department of Obstetrics and Gynecology, Fondazione Policlinico Tor Vergata

Address: 00133, Roma, Italy

Tel.: +39 620908124

E-mail: giuseppe.rizzo@uniroma2.it

Conflict of interests. The authors declare that there is no conflict of interests.

Financial support. The study was not sponsored (own resources).

Received: 21.08 .2021

Accepted: 29.08 .2021

Date of publication: 29.09 .2021 


\title{
Рост плода и гемодинамика при инфицировании SARS-CoV-2: краткий обзор литературы
}

\author{
Д. Риццо ${ }^{1,}$, И. Маппа ${ }^{1}$, П. Макина 1 , В. О. Бицадзе ${ }^{2}$, Д.Х. Хизроева ${ }^{2}$, А.Д. Макацария ${ }^{2}$ \\ ${ }^{1}$ Университет Рома Тор Вергата, Центральная поликлиника Тор Вергата, \\ отделение медицины матери и плода, Госпиталь Кристо Ре \\ 00167, Рим, Италия \\ ${ }^{2}$ ФГАОУ ВО «Первый Московский государственный медицинский университет им. И.М. Сеченова» \\ Минздрава России (Сеченовский Университет) \\ ул. Трубеикая, д. 8, стр. 2, г. Москва, 119991, Россия
}

\begin{abstract}
Аннотация
Коронавирус тяжелого острого респираторного синдрома 2 (SARS-CoV-2) - вирус, который преодолел видовой барьер и стал причиной заболевания человека с 2019 года (COrona VIrus Disease 2019, COVID-19). Беременные женщины потенциально подвержены более высокому риску заражения SARS-CoV-2 по сравнению с небеременными женщинами соответствующей контрольной группы. Беременность также ассоциирована с повышенным риском развития тяжелого SARS-CoV-2, включая заболевания дыхательной системы, госпитализацию в отделение интенсивной терапии и смертность, даже после поправки на сопутствующие фракторы риска. Более того, данные о влиянии на показатели плода, включая преждевременные роды и перинатальную заболеваемость, все еще противоречивы. Риск вертикальной передачи, то есть передачи SARS-CoV-2 от матери к плоду или новорожденному, считается низким, однако есть доказательства, что в плаценте, инфицированной SARS-CoV-2, достаточно часто определяются гистопатологические признаки гипоперфузии и воспаления плаценты. В этом обзоре мы представим имеющиеся данные о влиянии инфекции SARS-CoV-2 на рост плода и гемодинамику матери.
\end{abstract}

Ключевые слова: инфекция SARS-CoV-2; COVID-19; рост плода; доплерография маточной артерии; допплерография плода

Рубрики MeSH:

БЕРЕМЕННОСТИ ОСЛОЖНЕНИЯ ИНФЕКЦИОННЫЕ - ДИАГНОСТИКА

БЕРЕМЕННОСТИ ОСЛОЖНЕНИЯ ИНФЕКЦИОННЫЕ - ПАТОФИЗИОЛОГИЯ

ТЯЖЕЛЫЙ ОСТРЫЙ РЕСПИРАТОРНЫЙ СИНДРОМ - ДИАГНОСТИКА

ТЯЖЕЛЫЙ ОСТРЫЙ РЕСПИРАТОРНЫЙ СИНДРОМ - ОСЛОЖНЕНИЯ

ТЯЖЕЛЫЙ ОСТРЫЙ РЕСПИРАТОРНЫЙ СИНДРОМ - ПАТОФИЗИОЛОГИЯ

ПЛОД - ДИАГНОСТИЧЕСКОЕ ИЗОБРАЖЕНИЕ

ПЛОД - ПАТОФИЗИОЛОГИЯ

ПЛАЦЕНТАРНОЕ КРОВООБРАЩЕНИЕ

Для цитирования: Риццо Д., Маппа И., Макина П., Бицадзе В.О., Хизроева Д.Х., Макацария А.Д. Рост плода и гемодинамика при инфицировании SARS-CoV-2: краткий обзор литературы. Сеченовский вестник. 2021; 12(2): 20-25. https://doi.org/10.47093/2218-7332.2021.12.2.20-25

КОНТАКТНАЯ ИНФОРМАЦИЯ:

Джузеппе Риццо, MD, профессор, Университет Рома Тор Вергата, зав. кафедрой акушерства и гинекологии, Центральная поликлиника Тор Вергата

Адрес: 00133, Рим, Италия.

Tel.: +39 620908124

E-mail: giuseppe.rizzo@uniroma2.it

Конфликт интересов. Авторы заявляют об отсутствии конфликта интересов.

Финансирование. Исследование не имело спонсорской поддержки (собственные ресурсы).

Поступила: 21.08 .2021

Принята: 29.08.2021

Дата печати: 29.09.2021 
List of abbreviation

SARS-CoV-2 - severe acute respiratory syndrome coronavirus 2
UVBF - umbilical vein blood flow

UVBF/AC - umbilical vein blood flow normalized for fetal abdominal circumference

\section{HIGHLIGHTS}

SARS-CoV-2 virus induce changes in the placenta, mainly characterized by hypoperfusion and inflammation

These placenta changes do not seem associated with changes in fetal growth and hemodynamics

Women experiencing SARS-CoV-2 infection should be reassured of the low risk of adverse perinatal outcome

An intensive fetal surveillance should be considered when other pregnancy complications are present in addition to COVID 19 infection
КЛЮЧЕВЫЕ ПОЛОЖЕНИЯ

Bирус SARS-CoV-2 вызывает изменения плаценты, которые в основном характеризуются гипоперфузией и воспалением

Эти изменения плаценты, по-видимому, не ассоциированы с изменениями роста плода и гемодинамики

Беременным женщинам с SARS-CoV-2 инфекцией необходимо дать информацию о низком риске неблагоприятных перинатальных исходов

При наличии других осложнений беременности следует рассмотреть возможность интенсивного наблюдения за плодом
Severe acute respiratory syndrome coronavirus 2 (SARS-CoV-2) infection started and spread from the end of 2019 and up to now is still a major issue of concern for Public Health, with a daily worldwide increase of new cases of infection that may require admission to hospital and or to intensive care unit, and deaths ${ }^{1}[1,2]$.

Pregnancy has been reported to be an independent risk factor for adverse outcomes in women with SARSCoV-2 infection, especially if other co-morbidities, such as diabetes or pre-eclampsia co-exist. The peculiar changes occurring in the cardiorespiratory system during pregnancy may be partially responsible for the increased burden of maternal morbidities observed in these women when compared to the non-pregnant general population [3-5].

SARS-CoV-2 infection has been reported to potentially affect the placenta. There is an increasing number of reports showing a high prevalence of placental related to hypoperfusion and inflammation in women with SARS-CoV-2 infection when compared to control pregnant population women [6-10]. The potential association between SARS-CoV-2 and impaired placental function is crucial because it might lead to changes in fetal growth, hemodynamic decompensation and increased risk of perinatal mortality and morbidity.

The objective of this review is to quantify the effects of SARS-CoV-2 infection on placental changes, fetal growth, and hemodynamics during pregnancy.

\section{PLACENTAL CHANGES}

The findings from our systematic review showed that a large proportion of pregnancies complicated by SARS-CoV-2 infection have placental histopathological abnormalities consistent with placental inflammation and hypoperfusion, while only about $17.4 \%$ of these pregnancies showed no placental anomalies. Sub-group analyses according to the presence of maternal symptoms or high-risk pregnancy showed similar results with the large majority of placenta from women with SARS-CoV-2 infection in pregnancy [11].

The recently reported association between SARSCoV-2 infection in pregnancy and stillbirth questions whether the placenta can be a targeted host to viral infection. A population study from the United Kingdom, including more than 3000 pregnancies with laboratory confirmed SARS-CoV-2 infection, reported that stillbirth was significantly more common in women when compared to those without the infection ( 8.5 per 1000 vs 3.4 per 1000) with an adjusted odds ratio of $2.21(95 \%$ confidence interval 1.58-3.11; $p<0.001$ ) [12].

It has been shown that the COVID-19 virus enters into human cells by interacting with the angiotensinconverting-enzyme receptor and there is evidence that the concentrations of these receptors are increased in the pregnant uterus and placenta [11]. These findings have been subsequently confirmed by the increased prevalence of signs of decidual arteriopathy in the placenta of infected pregnant women, demonstrating a link between infection and impaired placental function. The potential mechanisms responsible for the higher risk of fetal death in the pregnancies may be explained on the basis of a direct effect of the virus on the placenta, inducing inflammation and necrosis or, alternatively, to a secondary effect due to placenta hypoperfusion induced by the compromised hemodynamic status of the mother. The results from this systematic review showed a high rate of maternal and fetal vascular malperfusion, associated with acute and chronic inflammatory pathology, potentially linking the observed increased risk of stillbirth with placental anomalies.

\section{EFFECTS ON FETAL GROWTH}

The Royal College of Obstetricians and Gynecologists (RCOG) recommends that pregnant women recovering

\footnotetext{
Centers for Disease Control and Prevention (CDC) Data on COVID-19 during pregnancy: weekly COVID-19 pregnancy data (2021) https://www.cdc.gov/coronavirus/2019-ncov/cases-updates/special-populations/pregnancy-data-on-covid-19.html. Accessed Aug ${ }^{\text {rd }}$, 2021.
} 
A

- Controls / Контроль

- SARS-CoV-2 affected mothers /

Матери, инфицированные SARS-CoV-2

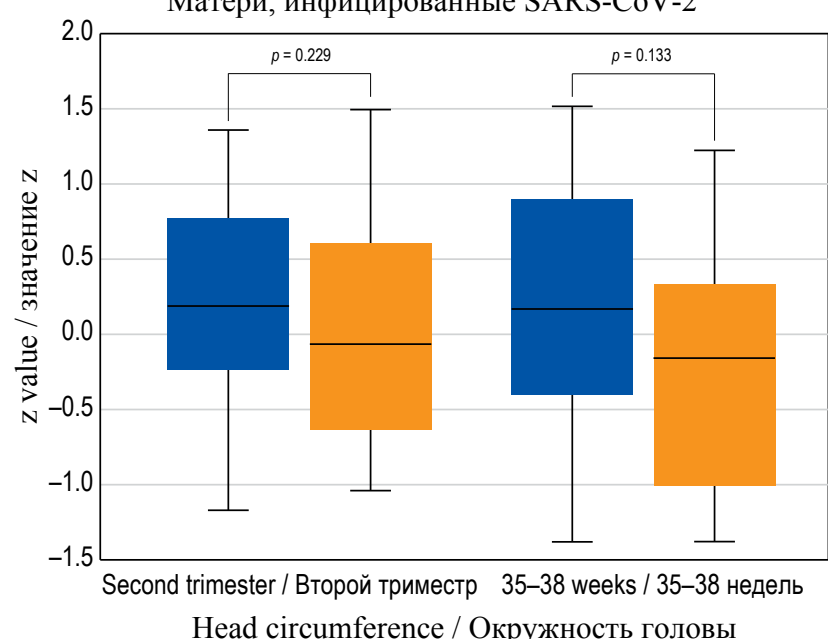

Head circumference / Окружность головы
B Controls / Контроль

- SARS-CoV-2 affected mothers /

Матери, инфицированные SARS-CoV-2

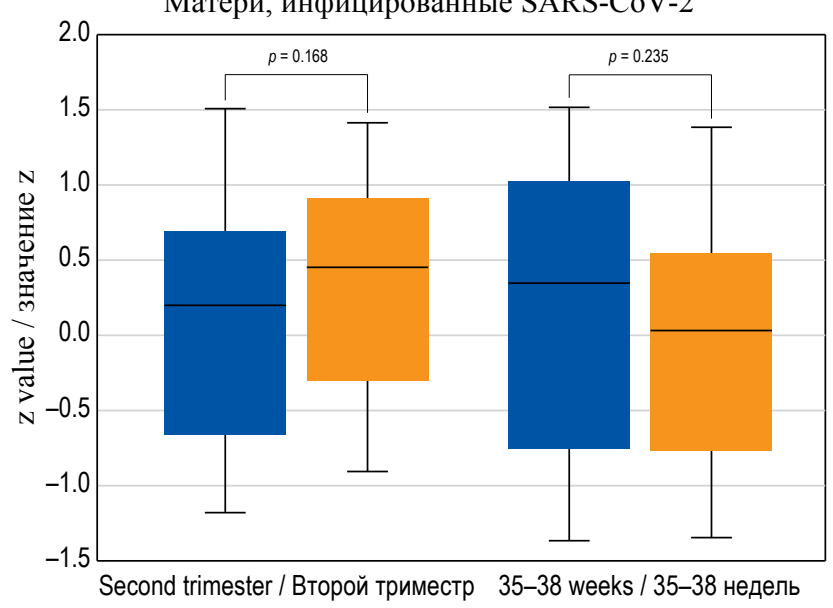

Estimated fetal weight / Расчетная масса плода

FIG. 1. Box-whisker plots of head circumference (A), and estimated fetal weight (B): $z$ value in SARS-CoV-2 affected mothers and in control group in the second trimester, and at 35-38 weeks. (Diagram based on data from [13].)

PИC. 1. Графики окружности головы (A) и расчетной массы плода (B): значение z у матерей, инфицированных SARS$\mathrm{CoV}-2$, и в контрольной группе во втором триместре и на сроках 35-38 недель. (Диаграмма построена по данным [13].)

from SARS-CoV-2 infection should be offered a growth scan, and at least a fetal growth scan, approximately 14 days after recovering from the illness (or $>21$ days from prior fetal biometry ultrasound), unless there is a pre-existing clinical reason for an earlier scan. This suggests that these pregnancies might theoretically be at a higher risk of fetal growth restriction ${ }^{2}$.

Despite this, there is still a substantial lack of evidence on the actual role of SARS-CoV-2 infection in affecting fetal growth. We have previously reported [13] that, in women with mildly symptomatic infection, there was no difference in estimated fetal weight and fetal growth velocity in pregnancies complicated by Sars-CoV-2 infection compared to those not. However, this study was hampered by the small sample size, lack of severely symptomatic cases and heterogeneity in the gestational age at infection. Figure 1 shows the absence of effects on the $z$ value (i.e., the number of standard deviations that the value differs from the expected mean for gestation) on head circumference and the estimated fetal weight in women experiencing SARS-CoV-2 infection.

Despite the absence of evident changes in fetal growth, it should be considered that maternal vascular hypoperfusion is potentially associated with a higher risk of impaired placental function, and stillbirth. Therefore, particular care may be necessary in pregnancies, and particularly those associated with other risk factors.

\section{HEMODYNAMIC EFFECTS}

A significant proportion of women with SARS-Cov-2 infection in pregnancy show placental histopathological abnormalities suggesting placental hypoperfusion and inflammation. Doppler ultrasonography is considered a reliable technique to evaluate hemodynamic changes in fetal and maternal circulation. We therefore tested whether SARS-CoV-2 infection can alter in maternal and fetal Dopplers [13]. There was no difference in either mean uterine artery, umbilical and middle cerebral artery pulsatility index and cerebral placental ratio z-scores [14] between pregnancies complicated and those not complicated by SARS-CoV-2 infection (Fig. 2).

We recently hypothesized that placental changes due to COVID-19 infection may lead to impaired umbilical vein blood flow (UVBF) and subsequent fetal cardiac remodeling [15]. The objective was to compare the UVBF and fetal cardiac function in pregnancies complicated and in those not complicated by COVID-19 infection in a prospective case-control study of consecutive pregnancies complicated by COVID-19 infection during the second half of pregnancy matched with unaffected women.

Measurements of UVBF normalized for fetal abdominal circumference (UVBF/AC), the atrial area (AA) and ventricular sphericity indices (SI) were assessed and compared between the two study groups. There was no difference in UVBF/AC values. Likewise, there was no difference in the left and right AA and SI suggesting that pregnancies complicated by COVID-19 infection showed no reduction in UVBF and are not at higher risk of cardiac remodeling.

\section{CONCLUSION}

In the management of pregnancies complicated by SARS-CoV-2 infection there is still debate as to whether

2 Royal College of Obstetricians and Gynaecologists. Coronavirus (COVID-19) Infection in Pregnancy Information for healthcare professionals Version 13: Published Friday 19 February 2021 https://www.rcog.org.uk/ Accessed Aug 6 ${ }^{\text {th }}, 2021$. 
A

- Controls / Контроль

- SARS-CoV-2 affected mothers /

Матери, инфицированные SARS-CoV-2

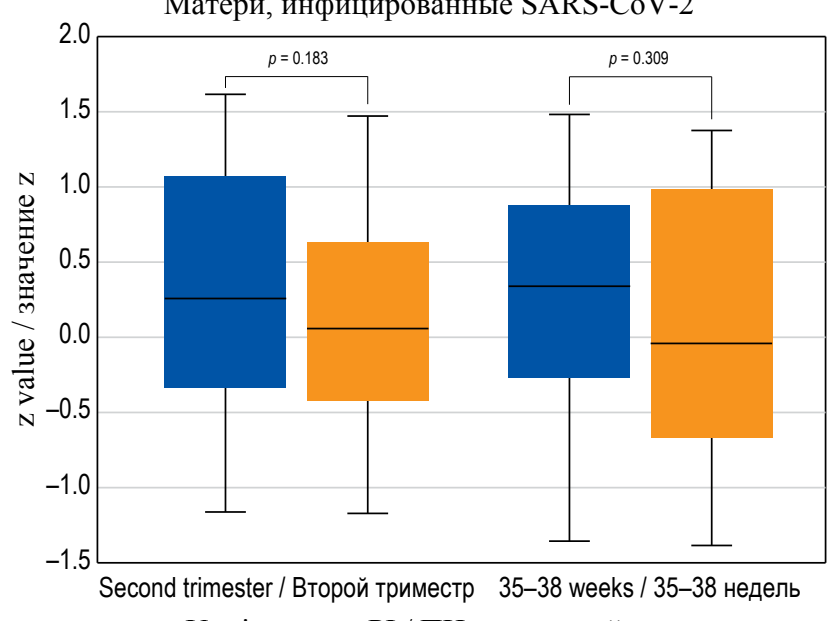

Uterine artery PI / ПИ в маточной артерии
B Controls / Контроль

- SARS-CoV-2 affected mothers /

Матери, инфицированные SARS-CoV-2

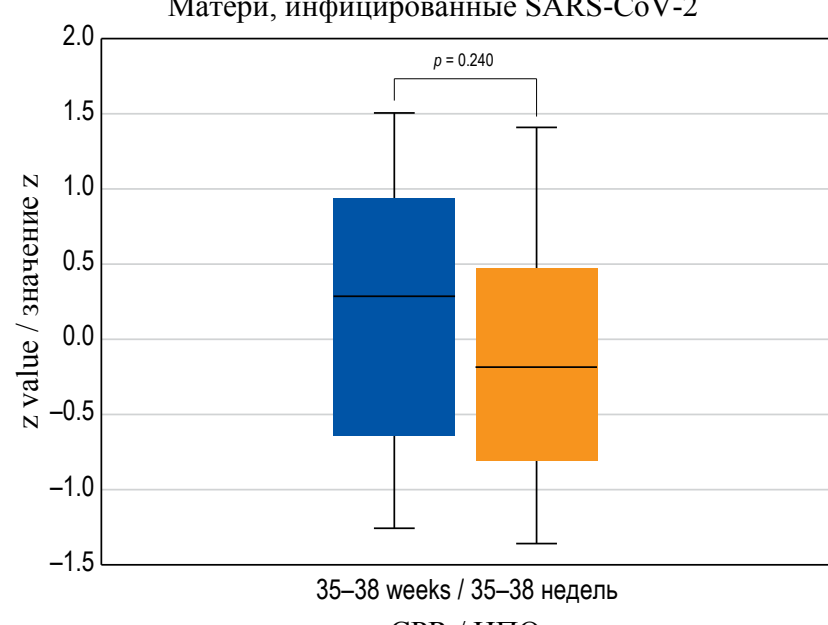

СРR / ЦПО

FIG. 2. Box-whisker plots of uterine artery pulsatility index (A) and cerebral placental ratio (B): $z$ value in SARS-CoV-2 affected mothers and in control group in the second trimester and at 35-38 weeks. (Diagram based on data from [14].)

РИС. 2. Графики пульсационного индекса в маточной артерии (А) и церебро-плацентарного отношения (В): значение z у матерей, инфицированных SARS-CoV-2, и в контрольной группе во втором триместре и на сроках 35-38 недель. (Диаграмма построена по данным [14].)

Note: PI - pulsatility index. CPR - cerebral placental ratio.

Примечание: ПИ - пульсационный индекс. ЦПО - церебро-плацентарное отношение.

more frequent fetal surveillance should be applied to these women or whether they should be followed in the standard manner. The data reported in this review provide no evidence that a policy of serial ultrasonography scans to assess the velocity of fetal growth is necessary in view of the lack of association between infection and impaired fetal growth. Furthermore, in women with SARSCoV-2 infection the risk of stillbirth has been reported to be not significantly different from that of the control pregnant population. Consequently, women with SARSCoV-2 infection should be reassured of the low risk of experiencing adverse fetal outcomes. This concept should be emphasised since there is evidence that pregnant women with SARS-CoV-2 infection showed increased levels of anxiety due to the specific concerns about the potential negative effect of infection on their fetus and newborn [16].

\section{AUTHOR CONTRIBUTIONS}

Giuseppe Rizzo, Ilenia Mappa and Pavjola Maquina equally contributed to the design, participated in writing the text of the manuscript and its interpretation. Victoria O. Bitsadze, Jamilya Kh. Khizroeva and Alexander D. Makatsariya developed the general concept of the article and supervised its writing. All authors participated in the discussion and editing of the work. All authors approved the final version of the publication.

\section{REFERENCES / ЛИТЕРАTУPA}

1. Di Mascio D., Khalil A., Saccone G., et al. Outcome of coronavirus spectrum infections (SARS, MERS, COVID-19) during pregnancy: a systematic review and meta-analysis. Am J Obstet Gynecol MFM. 2020 May; 2(2): 100107.
Pregnancies with SARS-CoV-2 infection showed no greater risk of developing fetal growth restriction or fetal compromise. Even though sub-group analysis according to the severity of the disease and gestational age at infection could not be performed, it might be reasonable to offer women recovered from SARS-CoV-2 infection an additional growth scan in the third trimester to rule out the possibility of reduced fetal growth due to impaired placental function, and therefore, reassure the parents.

More importantly, additional ultrasound scans throughout the pregnancy might be required in women presenting with objective risk factors for growth restriction such as a previous complicated pregnancy, abnormal placental biomarkers or increased pulsatility index in the uterine arteries because in these women SARS-CoV-2 infection may worsen an already compromised placenta.

\section{ВКЛАД АВТОРОВ}

Д. Риццо, И. Маппа и П. Макина в равной степени внесли свой вклад в дизайн, участвовали в написании текста рукописи и его интерпретации. В.О. Бицадзе, Д.Х. Хизроева и А.Д. Макацария разработали общую концепцию статьи и руководили ее написанием. Все авторы участвовали в обсуждении и редактировании работы. Все авторы одобрили окончательную версию публикации.

https://doi.org/10.1016/j.ajogmf.2020.100107. Epub 2020 Mar 25. PMID: 32292902.

2. Khalil A., Kalafat E., Benlioglu Cet., et al. SARS-CoV-2 infection in pregnancy: A systematic review and meta-analysis of clinical 
features and pregnancy outcomes. EClinicalMedicine. 2020 Aug; 25: 100446. https://doi.org/10.1016/j.eclinm.2020.100446. Epub 2020 Jul 3. PMID: 32838230.

3. Poon L.C., Yang H., Dumont S., et al. ISUOG Interim Guidance on coronavirus disease 2019 (COVID-19) during pregnancy and puerperium: information for healthcare professionals - an update. Ultrasound Obstet Gynecol. 2020 Jun; 55(6): 848-862. https://doi.org/10.1002/uog.22061. PMID: 32356590.

4. WAPM (World Association of Perinatal Medicine) Working Group on COVID-19. Maternal and perinatal outcomes of pregnant women with SARS-CoV-2 infection. Ultrasound Obstet Gynecol. 2021 Feb; 57(2): 232-241. https://doi.org/10.1002/uog.23107. Epub 2021 Jan 21. Erratum in: Ultrasound Obstet Gynecol. 2021 Aug 9. PMID: 32926494.

5. Di Mascio D., Sen C., Saccone G., et al. Risk factors associated with adverse fetal outcomes in pregnancies affected by coronavirus disease 2019 (COVID-19): a secondary analysis of the WAPM study on COVID-19. J Perinat Med. 2020 Nov 26; 48(9): 950-958. https://doi.org/10.1515/jpm-2020-0355. Erratum in: J Perinat Med. 2020 Dec 02; 49(1): 111-115. PMID: 32975205.

6. Malinowski A.K., Noureldin A., Othman M. COVID-19 susceptibility in pregnancy: Immune/inflammatory considerations, the role of placental ACE-2 and research considerations. Reprod Biol. 2020 Dec; 20(4): 568-572. https://doi.org/10.1016/j. repbio.2020.10.005. PMID: 33183974.

7. Dhaundiyal A., Kumari P., Jawalekar S.S., et al. Is highly expressed ACE 2 in pregnant women "a curse" in times of COVID-19 pandemic? Life Sci. 2021 Jan 1; 264: 118676. https://doi.org/10.1016/j.lfs.2020.118676. PMID: 33129880.

8. Shanes E.D., Mithal L.B., Otero S., et al. Placental pathology in COVID-19. Am J Clin Pathol. 2020 Jun 8; 154(1): 23-32. https://oi.org/10.1093/ajcp/aqaa089. PMID: 32441303.

9. Baergen R.N., Heller D.S. Placental pathology in Covid-19 Positive mothers: preliminary findings. Pediatr Dev Pathol. 2020 MayJun; 23(3): 177-180. https://doi.org/10.1177/1093526620925569. PMID: 32397896.
10. Schwartz D.A., Baldewijns M., Benachi A., et al. Chronic histiocytic intervillositis with trophoblast necrosis are risk factors associated with placental infection from coronavirus disease 19 (COVID-19) and intrauterine maternal-fetal systemic acute respiratory coronavirus 2 (SARSCoV-2) transmission in liveborn and stillborn infants. Arch Pathol Lab Med. 2021 May 1; 145(5): 517-528. https://doi.org/ 10.5858/arpa.2020-0771-SA. PMID: 33393592.

11. Di Girolamo R., Khalil A., Alameddine S., et al. Placental histopathology after SARS-CoV-2 infection in pregnancy: a systematic review and meta-analysis, American Journal of Obstetrics \& Gynecology MFM, 2021, 100468, https://doi. org/10.1016/j.ajogmf.2021.100468

12. Gurol-Urganci I., Jardine J.E., Carroll F., et al. Maternal and perinatal outcomes of pregnant women with SARS-CoV-2 infection at the time of birth in England: national cohort study. Am J Obstet Gynecol. 2021 May 20; S0002-9378(21): 00565-2. https://doi.org/10.1016/j.ajog.2021.05.016. PMID: 34023315.

13. Rizzo G., Mappa I., Maqina P., et al. Effect of SARS-CoV-2 infection during the second half of pregnancy on fetal growth and hemodynamics: a prospective study. Acta Obstet Gynecol Scand. 2021 Jun; 100(6): 1034-1039. https://doi.org/10.1111/ aogs.14130. PMID: 33604901

14. Rizzo G., Pietrolucci M.E., Mappa I., et al. Modeling pulsatility index nomograms from different maternal and fetal vessels by quantile regression at 24-40 weeks of gestation: a prospective cross-sectional study. J Matern Fetal Neonatal Med. 2020 May 25. https://doi.org/10.1080/14767058.2020.1767060

15. Rizzo G., Mappa I., Maqina P., et al. Did severe acute respiratory syndrome COVID-19 infection affect umbilical vein blood flow and fetal cardiac function? Ultras Obstet Gynecol 2021 in press.

16. Mappa I., Distefano F.A., Rizzo G. Effects of coronavirus 19 pandemic on maternal anxiety during pregnancy: a prospectic observational study. J Perinat Med. 2020 Jul 28; 48(6): 545-550. https://doi.org/ 10.1515/jpm-2020-0182. PMID: 32598320.

\section{INFORMATION ABOUT THE AUTHORS / ИНФОРМАЦИЯ ОБ АВТОРАХ}

Giuseppe Rizzo ${ }^{\bowtie}, M D$, Professor and Chairman, University of Rome Tor Vergata, Department of Obstetrics and Gynecology, Fondazione Policlinico Tor Vergata.

ORCID: https://orcid.org/0000-0002-5525-4353

Ilenia Mappa, MD, PhD, University of Rome Tor Vergata, Division of Maternal Fetal Medicine, Ospedale Cristo Re. ORCID: https://orcid.org/0000-0002-9866-3050

Pavjola Maqina, MD, University of Rome Tor Vergata, Division of Maternal Fetal Medicine, Ospedale Cristo Re. ORCID: https://orcid.org/0000-0002-7286-4161

Victoria O. Bitsadze, Dr. of Sci. (Medicine), Professor, Department of Obstetrics and Gynecology, Sechenov First Moscow State Medical University (Sechenov University).

ORCID: https://orcid.org/0000-0001-8404-1042

Jamilya Kh. Khizroeva, Dr. of Sci. (Medicine), Professor, Department of Obstetrics and Gynecology, Sechenov First Moscow State Medical University (Sechenov University).

ORCID: https://orcid.org/0000-0002-0725-9686

Alexander D. Makatsariya, Dr. of Sci. (Medicine), Professor, Academician RAS, Head of Department of Obstetrics and Gynecology, Sechenov First Moscow State Medical University (Sechenov University).

ORCID: https://orcid.org/0000-0001-7415-4633
Риццо Джузеппе ${ }^{凶}, \mathrm{MD}$, профессор, Университет Рома Тор Вергата, зав. кафедрой акушерства и гинекологии, Центральная поликлиника Тор Вергата.

ORCID: https://orcid.org/0000-0002-5525-4353

Маппа Иления, MD, PhD, Университет Рома Тор Вергата, отделение медицины матери и плода, Госпиталь Кристо Ре. ORCID: https://orcid.org/0000-0002-9866-3050

Макина Паула, MD, Университет Рома Тор Вергата, отделение медицины матери и плода, Госпиталь Кристо Ре. ORCID: https://orcid.org/0000-0002-5178-3354

Бицадзе Виктория Омаровна, д-р мед. наук, профессор кафедры акушерства и гинекологии ФГАОУ ВО «Первый МГМУ им. И.М. Сеченова» Минздрава России (Сеченовский Университет)

ORCID: https://orcid.org/0000-0001-8404-1042

Хизроева Джамиля Хизриевна, д-р мед. наук, профессор кафедры акушерства и гинекологии ФГАОУ ВО «Первый МГМУ им. И.М. Сеченова» Минздрава России (Сеченовский Университет).

ORCID: https://orcid.org/0000-0002-0725-9686

Макацария Александр Давидович, д-р мед. наук, професcop, академик РАН, зав. кафедрой акушерства и гинекологии ФГАОУ ВО «Первый МГМУ им. И.М. Сеченова» Минздрава России (Сеченовский Университет).

ORCID: https://orcid.org/0000-0001-7415-4633

\footnotetext{
Автор, ответственный за переписку / Corresponding author
} 